\title{
Postmodernisme, postmoderne organisaties en implicaties voor management control
}

\section{Hans Strikwerda}

SAMENVATTING Bij alle pogingen om de effectiviteit van management control te verbeteren, wordt ook wel gewezen op de factor cultuur, respectievelijk het sociale systeem, maar daarbij wordt uitgegaan van een mensbeeld zoals dat verondersteld wordt in de neo-klassieke economie. Er is een aantal sociologische ontwikkelingen gaande in onze samenleving die raken aan de grondslagen van het vakgebied management control. Deze ontwikkelingen worden goeddeels beschreven door wat het post-modernisme wordt genoemd. Het geheel aan inzichten dat met deze term wordt aangeduid, maakt duidelijk dat de nagestreefde effectiviteit van management control niet met de bestaande technieken en opvattingen kan worden gerealiseerd. We staan aan het begin van een nieuwe ontwikkeling en dit artikel beschrijft het begin daarvan.

\section{Inleiding}

De effectiviteit van management control in de onderneming of instelling is geen technisch vraagstuk, maar een gedragswetenschappelijk vraagstuk. Management control is erop gericht het gedrag van individuen in de organisatie zodanig te beïnvloeden dat de activiteiten van die individuen en afdelingen waarin ze georganiseerd zijn, effectiever en efficiënter gecoördineerd

Prof. Dr. J. Strikwerda is hoogleraar organisatieleer en organisatieverandering (internal governance) aan de Universiteit van Amsterdam, Faculteit voor Economische Wetenschappen en Econometrie, afdeling business studies en verbonden aan de postdoctorale opleidingen voor controller en operational auditor; senior fellow van het Nolan Norton Institute en management consultant bij Nolan, Norton \& Co. Dankbaar is gebruikgemaakt van de commentaren en suggesties van enkele anonieme reviewers. worden dan het geval zou zijn dan door coördinatie via het marktmechanisme (om de collectieve doelstelling te realiseren). De coördinatie van activiteiten en daarmee ook de management control, verloopt via een scala van mechanismen, waaronder ook sociaalpsychologische mechanismen. Met dit laatste speelt ook het zelfbeeld van de mens een rol in de werking en de effectiviteit van management control. Dit zelfbeeld is in de geschiedenis van de mens aan verandering onderhevig als gevolg van het continue proces van collectieve bewustwording in de westerse samenleving. Dit continue proces van bewustwording heeft zijn weerslag op de rol van wetten, gezag, de omgang tussen mensen en via die weg ook op de management control binnen ondernemingen en instellingen. De discussie over het veranderende zelfbeeld van de mens wordt wel gevoerd onder de term postmodernisme. Daarmee verbonden is er ook een discussie over postmoderne organisaties. De vraag kan dus worden gesteld of de idee van de postmoderne mens en de postmoderne organisatie consequenties kan hebben voor de rol, aard en effectiviteit van management control. In deze verkenning zal blijken dat er wel zoiets bestaat als een postmoderne mens, idem een postmoderne economie, maar niet zoiets als een postmoderne organisatie. In die discrepantie ligt toch wel een issue voor management control.

Het vak management control is gevormd in de jaren vijftig van de twintigste eeuw (Anthony \& Govindarajan, 1995: xii), sindsdien is er zoveel veranderd dat de vraag gesteld mag worden of de sociaal-wetenschappelijke grondslagen waarop management control berust, nog wel opgaan.

In dit artikel volgt in paragraaf 2 eerst een samenvatting van de grondslagen van management control. In de paragrafen 3 tot en met 5 wordt achtereenvolgens uiteengezet wat onder postmodernisme wordt verstaan, idem onder de post-moderne mens en dat 
er weliswaar wordt gesproken over post-moderne organisaties, maar dat die nu juist niet bestaan, maar wel weer post-moderne economische exploitatie. In paragraaf 6 worden de implicaties van het postmodernisme voor management control beschreven. In paragraaf 7 ten slotte wordt een suggestie gedaan hoe het vakgebied management control zich verder zou kunnen ontwikkelen, respectievelijk waarop de discussie en het onderzoek zich zouden moeten concentreren, maar dit is meer een aanzet voor discussie dan een conclusie.

\section{Fundamenten van management control}

In de twee meest gehanteerde handboeken voor management control (Anthony et al., 1995; Merchant, 1998) wordt niet expliciet uiteengezet op welke aannames het vak management control berust. Elk vakgebied berust op een aantal - voorwetenschappelijke - aannames en is evenals zijn beoefenaren kind van de tijd waarin het geconcipieerd en volwassen geworden is. Management control als vakgebied is, als onderdeel van de leer van de interne organisatie van ondernemingen, een product van de economie van de tweede industriële revolutie. We mogen aannemen dat we in een andere economie terecht zijn gekomen (Castells, 1996; DeLong en Summer, 2001; Jensen, 2000; Strikwerda, 2000)․ Dan moet de vraag worden gesteld of de aannames waarop het vakgebied management control berust, in die nieuwe economie nog wel opgaan. Zonder de vraag naar de grondslagen te stellen, lopen we het risico de nu ervaren ineffectiviteit in de toepassing van technieken uit de management control toe te schrijven aan gebrek aan training, discipline en volharding of proberen we technieken te verfijnen om die ineffectiviteit op te lossen, terwijl meer fundamentele vernieuwing nodig is. De fundamenten waarop een vakgebied als management control berust, kunnen worden onderscheiden in twee categorieën.

- Een eerste categorie bestaat uit economisch-juridische uitgangspunten. Zo berust control in essentie daarop dat aan de gesalarieerde manager van een onderneming, respectievelijk de werknemer wel het gebruiksrecht op productiemiddelen wordt gedelegeerd, maar niet het vruchtgebruik en evenmin het vervreemdingsrecht (Furubotn en Richter, 2000, pp. 77-79). Verder wordt in de management control verondersteld dat de kennis die de onderneming exploiteert codificeerbaar is, algemeen van karakter en niet persoonsgebonden (Jensen, 1998). Kennis, zo wordt verder verondersteld, wordt steeds geëxploi- teerd doordat deze belichaamd is in discrete fysieke producten waarvan de winstgevendheid onderworpen is aan de wet van de afnemende meeropbrengst. Verder wordt verondersteld dat waardecreatie als basis voor de winst van de onderneming plaatsvindt binnen het - juridische - domein van de onderneming. Deze traditionele grondslagen van management control vinden we terug in de interne organisatie: controle op fysieke productiemiddelen (observatie, afsluiting, controle aan de poort), direct toezicht op werkprocessen door een chef, kennis die in machines geïncorporeerd is, waardoor de onderneming niet of minder kwetsbaar is voor het weglopen van medewerkers.

- Een tweede categorie aannames ligt op het sociaalmaatschappelijke vlak. Hier gaat het om mensbeelden, het uitgangspunt dat er een objectief kenbare werkelijkheid is (objectieve, voor ieder geldende rapportages en cijfers), de legitimiteit van bovenpersoonlijke doelstellingen, utopisch denken als richtsnoer voor het stellen van doelen (management control is immers nodig omdat we doelen willen realiseren die niet uit de natuurlijke gang van zaken voortvloeien), arbeid als belangrijkste levensvervulling, beïnvloedbaarheid van gedrag via verschillende vormen van materiële en niet-materiële beloning, erkenning van gezag en wet, identificatie, socialisatie en dat individuen bewust een carrière nastreven. Jensen (1998) heeft in essentie uitgewerkt waarom wat hij noemt internal control niet meer werkt als gevolg van de omslag van algemene, niet-persoonsgebonden kennis naar specifieke, persoonsgebonden kennis.

In dit artikel wordt beargumenteerd dat en waarom als gevolg van sociale ontwikkelingen en meer fundamentele ontwikkelingen in de economie het vakgebied management control zich ook zal moeten bezinnen op haar grondslagen om zich aan te passen aan veranderende omstandigheden, wil het effectief kunnen blijven zijn.

\section{Wat is postmodernisme?}

Voor velen begint het post-modernisme met het boek van de Franse filosoof François Lyotard, The Postmodern Condition (1979). De moderne samenleving heeft niet enkel technologische vooruitgang gebracht. Ook zijn er nieuwe methoden gevonden om de continue verandering - economisch, institutioneel en technologisch - te rechtvaardigen (Myerson, 2001, p. 10). De moderne visie op de wereld garandeerde de legitimiteit van de moderne staat, de moderne economie en het moderne leven. Maar zo luidt de observatie 
van Lyotard, er is een proces gaande in de samenleving van 'delegitimisering'; we kunnen niet langer de onderliggende uitgangspunten voor onze levenswijze serieus nemen.

\section{Het einde van de grote verhalen}

Een van de symptomen van het postmodernisme, maar door velen gehanteerd als de definitie van postmodernisme, is wat Lyotard noemde 'het einde van de grote verhalen' (de Christelijke verlossing, de vooruitgang van de Verlichting, de Hegeliaanse geest, de eenheid van de romantiek, het nazisme, het Keynesiaanse evenwichtsdenken.) Het grote verhaal dat de moderne samenleving legitimeerde en bijeen hield was dat van de vooruitgang. Enerzijds werd dit gevoed door de wetenschappen, anderzijds door de westerse democratie. Wetenschap, die bedoeld is om feitelijk en waardevrij te zijn, kon enerzijds zichzelf slechts legitimeren door zich in dienst te stellen van de vooruitgangsgedachte en anderzijds door zich te laten gebruiken om de bestaande staat, instituties en maatschappelijke verhoudingen te legitimeren. Het proces van 'delegitimering' begint wanneer deze 'grand narrative' niet meer iedereen overtuigt. Daarmee zijn we in de samenleving niet alleen een gemeenschappelijk verhaal kwijt, maar ook een wereld die voor ieder een gemeenschappelijke kern heeft en gelegitimeerd is (Myerson, 2001, p. 12). Dit besef heeft vergaande consequenties. $\mathrm{Nu}$ wetenschap niet meer de politiek, de economie en de moraliteit in het maatschappelijk verkeer kan legitimeren, definieert en hanteert ieder zijn eigen regels. Het postmodernisme wordt dan ook wel eens samengevat als: 'er bestaan geen absolute waarheden'. Direct daaraan verbonden wordt dan gesteld dat er geen voor ieder geldende wetten, normen en moraliteit bestaan. Deze houding heeft ook consequenties voor hoe met nieuwe informatie en kennis wordt omgegaan. In de moderne samenleving werd nieuwe informatie en kennis steeds geïnterpreteerd in het licht van de vooruitgang, van de objectieve waarheid en van de legitimiteit van wetten en instituties. In de postmoderne tijd '.. new information breaks the world apart'. 'Postmodern Science' is about 'such things as undecidables, the limits of precise control. Conflicts characterized by incomplete information. It is changing the meaning of the word knowledge.' (Myerson, 2001, p. 14). In zijn boek The Differend bepleit Lyotard dat we een wereld zijn binnengegaan van ethische impasses, waarin: '(o)ne side's legitimacy does not imply the other's lack of legitimacy'. Deze gedachte gaf vervolgens voeding aan de idee van cultuurrelativisme en subjectivisme; ieder zijn mening. Lyotard stelde dat er niet langer universele toetsingsregels zijn. Oordelen zijn nog wel mogelijk, maar uitsluitend binnen specifieke situaties van lokaal gevalideerde verhalen. Er is sprake van een onmeetbaarheid; het is onmogelijk om een gemeenschappelijke norm toe te passen op onze verschillende besluiten en dilemma's.

\section{Postmodernisme en economie}

Degene die het postmodernisme in het economisch denken introduceerde, was de Amerikaan Frederic Jameson. Voor een samenvatting daarvan volgen we Anderson (1998). Jameson's interpretatie en toepassing van het postmodernisme bestaat uit vijf elementen.

- Het eerste element is de verankering van het postmodernisme in de veranderingen in de economische orde zelf; het postmodernisme als een nieuwe fase van de dominante productievorm in de economie. De ontwikkeling van de digitale elektronica, de dominantie van de multinationals, het overbrengen van productie naar lage lonen landen, de immense toename van de internationale financiële speculatie, de opkomst van de mediaconglomeraten hebben een diepe invloed op alle dimensies van de samenleving in de ontwikkelde industriële landen. In essentie is door deze ontwikkelingen de mens los van de natuur, los van de geografische dimensie komen te staan. Het gevolg daarvan is dat de dimensie cultuur van de samenleving van gelijke omvang en duur is geworden als de economie zelf (waar cultuur van oorsprong vooraf gaat aan economie en een veel tragere ontwikkeling kent dan de economie en daardoor een stabiliserende factor was als voorwaarde van het economisch proces). Het modernisme ontleende zijn doel en energie aan dat wat nog niet modern was; het postmodernisme is de fase van een existentiële crisis, er is geen doel. In essentie hebben we al het materiële wat utopisch ooit gedacht was en dus verschuift onze behoefte bevrediging naar niet-materiële gebieden.

- In zijn tweede element van het postmodernisme beschrijft Jameson de consequenties van het eerste element voor de belevingswereld van de mens. Een eerste gevolg is het verlies van elke betekenis van het verleden, zowel in de zin van hoop (op betere tijden) als in de zin van geheugen (en dus als bron van onderscheidende identiteit). De mens wordt daarmee contextloos. Dit resulteert in een diepteloosheid van het individu, die niet langer steun vindt in stabiele parameters (als geschiedenis, rituelen, religie, sociale verbanden). Het psychisch leven wordt onrustig, 
spasmodisch, met plotselinge dips in de gemoedsgesteldheid, wat een concentratie van energie op een object of idee uitsluit, evenals een historisch besef, om weer leidraad voor het eigen leven te ontwikkelen. Terwijl het collectieve historische bewustzijn vervlakt, beleeft het individu uitersten, van euforische hoogten als toeschouwer of als consument, tot de neerslachtigheid op de bodem van de nihilistische leegte van het bestaan, als gevangene van een maatschappelijke orde die elke vorm van sturing en betekenisverlening uitsluit (Anderson, 1998, p. 57).

- Het derde element in Jameson's beschrijving van het postmodernisme is de toepassing van het postmodernisme op alle cultuurvormen. Tot dan toe hadden verschillende auteurs over het postmodernisme telkens afzonderlijke cultuurvormen geanalyseerd en bekritiseerd, de literatuur, de architectuur, de filosofie en daarnaast de wetenschap. Jameson analyseert dat door de moderne film en de commerciële televisie de scheidslijn tussen de fine arts en de commercie begint te vervagen. De moderne film en televisie hebben tot effect dat voor de postmoderne mens de getoonde beelden evenzeer realiteit zijn als de fysieke realiteit (Rifkin, 2000, p. 197). Het gevolg hiervan is dat het continue proces van collectief bewust worden en zijn (Cornelius Castoriadis), van aannames en motieven, als voorwaarde voor de ontwikkeling van de samenleving, bedreigd wordt.

- Het vierde element in Jameson's beschrijving van het postmodernisme heeft betrekking op de sociale basis van het postmodernisme. In het modernisme was cultuur elitair, voortgebracht door randfiguren, minderheden en een voorhoede die wars van elk commercieel geschipper was. Kunst had iets heroïsch, had de macht om oppositioneel te zijn, had minachting voor conventionele smaak, maar belangrijker, het weerstond de verlokkingen van de markt. De cultuur van het postmoderne daarentegen is volks, de grens tussen cultuur met een $\mathrm{C}$ en cultuur met een $\mathrm{c}$ is opgeheven. In het postmoderne is cultuur onderwerp geworden van productie en consumptie. Daarmee is kunst niet meer een antagonisme in de economische orde waardoor de stabiliteit van de economische orde in het geding raakt.

- Het vijfde element ten slotte in Jameson beschrijving van het postmodernisme is het daarin besloten verzet tegen moralisme. Ethische doctrines vooronderstellen een sociale homogeniteit waarbinnen bovenpersoonlijke normen kunnen worden geformuleerd als uitdrukking van opvattingen over goed en kwaad. Zoals de Duitse filosoof Nietzsche eerder al had beweerd zijn deze normen in werkelijkheid vormen van machtsuitoefening en zo worden normen dan ook gerelativeerd.

\section{De postmoderne mens}

Binnen het vakgebied management control is niet geëxpliciteerd welk mensbeeld daarin wordt verondersteld. Gezien de periode waarin het vakgebied zijn beslag heeft gekregen, mag worden verondersteld dat daarin de moderne mens wordt verondersteld, die nu juist aan het veranderen is. De moderne mens gelooft in de beta-wetenschappen, in objectiviteit, is rationeel, heeft hoop. Er bestaat zoiets als een postmodern levensgevoel en zoiets als de postmoderne mens (Lindijer, 1998, p. 69; Rifkin, 2000, p. 210). Lindijer: 'Een postmodern mens voelt zich geen geheel, geen mens uit één stuk met een duidelijke identiteit, maar eerder een verdeeld en gefragmenteerd wezen. ... Postmoderne mensen horen zoveel stemmen in hun plurale samenleving, ze weten zich door diverse machten beheerst en ze maken geen deel uit van een bezielde, richtingwijzende beweging. Vaak zijn ze ambivalent, dubbelzinnig: ze willen het ene én het andere en komen moeilijk tot keuzes; met elke mogelijk keuze zijn voor- én nadelen verbonden. Argwaan is een element in het postmoderne levensgevoel. ... Postmodernen voelen zich meer op hun gemak in het lokale dan in het globale verband.

Daarmee is niet gezegd dat de postmoderne mens zwaarmoedig is, integendeel. De postmoderne mens beleeft plezier aan het extreme, de extase, het genot en zelfs pijn, want deze doorbreken de grip van machthebbers en ondergraven de bureaucratische controle (Lindijer, 1998, p. 78). De postmoderne mens denkt in meerdere paradigma's, is in staat een en hetzelfde vraagstuk van verschillende zijden te belichten zonder daarbij in de verwarring te raken die de moderne mens overkwam toen deze met concurrerende paradigma's werd geconfronteerd. Daarmee wordt de houding van de postmoderne mens tegenover het leven ook wel aangeduid met anything goes of n'importe quoi, een relativisme tegenover bestaande waarden en normen die door critici vaak als normloosheid wordt bestempeld.

\section{Wat houdt de discussie over de postmoderne organisatie in?}

In de literatuur wordt bij postmoderne organisaties gedacht aan netwerkorganisaties met semi-autonome cellen, platte organisaties, processen voor (spontane) 
zelforganisatie, zichzelf leidende teams, spontane strategievorming van onderop, horizontale accountability, en vooral flexibele organisatievormen (Best \& Kellner, 2001). Het gaat er om in één en dezelfde organisatie met meerdere definities van wat werkelijkheid is, tegelijk te kunnen opereren. De eerste die de term 'postmoderne organisatie' gebruikte, was Peter F. Drucker (1993). Drucker doelde op een loslaten van mechanische oorzaak-gevolgrelaties in ruil voor een nieuw patroon van doelen en processen. Zulke organisaties worden nu aangeduid met loosly coupled, fluïde, organisch, adhocratisch (Boje, 2001). De postmoderne organisatie is daarmee de antithese van de organisatie die naar structuur en processen gebaseerd is op de principes van het scientific management en Weber's principes voor de bureaucratie (en daarmee management control).

Clegg ziet de postmoderne organisatie als een tegenbeweging tegen te ver doorgevoerde specialisatie (Clegg, 1990). Wat Clegg in wezen doet, is in navolging van Schumacher's Small is Beautiful het romantiseren van een aantal organisatievormen (het Zweedse model, het Japanse model) die later failliet zouden blijken te zijn.

De bewustwording in de jaren tachtig van de tekortkomingen van het klassieke organisatiemodel hebben geleid tot tal van voorstellen voor 'nieuwe' organisatieprincipes. Voor een overzicht daarvan zie Boje en Prieto (2000). Het karakter van deze 'nieuwe' organisatieprincipes is meer die van een verzet tegen bestaande waarden, in de regel gedefinieerd in een reactie op, een omkering van 'oude' principes (verticale planning $\longleftrightarrow$ horizontale planning, boss centered people centered), zonder dat daarbij sprake is van een dieper doordenken van veranderingen.

\section{Twijfels bij de idee van de postmoderne organisatie}

Wat we zien in de beschrijving van de postmoderne organisatie is meer een reactie op een aantal disfunctionele aspecten van het dominante organisatiemodel uit de economie van de tweede industriële revolutie (1875- \pm 1975$)$ dan dat het een systematische synthese is van de consequenties van nieuwe maatschappelijke, economische verhoudingen en nieuwe technologieën. Door de instrumentele omgang met theorieën, zonder begrip van onderliggende juridische aspecten, economische wetmatigheden en sociaal-psychologische patronen zitten de profeten over de postmoderne organisatie vast in modernistische opvattingen die ze zo verfoeien, ze zijn gevangene van hun eigen postmoderne oppervlakkigheid. Vandaar ook dat er auteurs zijn die in het geheel geen postmoderne organisaties zien, zoals Watson bijvoorbeeld. 'The labeling of more flexible forms of bureaucratic structure and culture as 'postmodern' or 'post-bureaucratic' is unhelpful. It is unrealistic to suggest that there is something new occurring to work organizations at the level of the basic organizing principles. There is no postmodern or post-bureaucratic organizational form available to us that is essentially different from the modernist bureaucratic organization' (Watson, 2002, p. 254). David Boje heeft scherpe kritiek op ondernemingen als Nike en Disney die zichzelf als postmoderne ondernemingen presenteren naar het publiek, maar in hun fabrieken en back stage nog met Tayloriaanse organisatievormen werken (Boje, 2001). Maar daarin zou nu juist wel eens de kern van het probleem kunnen schuilen: er zijn wel postmoderne vormen van economische exploitatie (van cultuur, ervaringen, beelden, emoties); de organisatie als instrument om die exploitatie te realiseren moet vanwege zijn instrumentele rol modernistisch zijn.

\section{Postmoderne vormen van economische exploitatie}

Terwijl het hoogst twijfelachtig is of er postmoderne organisaties bestaan, zijn er veel sterkere aanwijzingen dat er in de economie zelf wel sprake is van veranderingen die de fundamenten van management control raken. De bestaande systemen en methoden voor management control gaan er vanuit dat de kennis die ondernemingen exploiteren algemeen, codificeerbaar en niet persoonsgebonden is, dat deze kennis wordt geëxploiteerd belichaamd in discrete fysieke goederen. In de economie is er sprake van een verschuiving van de exploitatie van fysieke goederen naar immateriële goederen (Rifkin, 2000). Daarmee treedt er ook een verschuiving op in de aard van de kennis die wordt geëxploiteerd. In het geval van de exploitatie van immateriële, of zoals Rifkin dat noemt, cultuurgoederen, is er sprake van een ander type kennis dat wordt geëxploiteerd, specifieke kennis, die soms wel, soms niet los gemaakt kan worden van de kenniswerker. In het algemeen geldt dat specifieke kennis persoonsgebonden is en daarmee kostbaar over te dragen op andere personen of afdelingen (Jensen, 1998, p. 103). Persoonsgebonden kennis impliceert ook dat de werkgever geen volledige controle meer heeft op het vervreemdingsrecht, loopt de professional weg, dan kan de werkgever niet verhinderen dat deze zijn kennis en ervaring meeneemt en elders toepast. Dit verklaart volgens Jensen dan ook de failure of internal control in de moderne onderneming (Jensen, 2000 , p. 16). Dit falen is in deze analyse in essentie 
een eigendomsvraagstuk, niet een effectiviteitvraagstuk van management control of het hanteren van verkeerde accounting uitgangspunten.

\section{De implicaties voor de fundamenten van management control}

Op welke wijze zouden de geschetste ontwikkelingen de fundamenten van management control en daarmee zijn effectiviteit in een veranderende economie kunnen raken? Het zou om de volgende aspecten kunnen gaan.

- Een eerste aspect is dat van het vervreemdingsrecht. De raison d'être van management control is de scheiding van eigendom en exploitatie van die eigendom door gesalarieerden. Als nu, wat Rifkin signaleert, fysiek kapitaal verdrongen wordt door immaterieel kapitaal en als het zo is dat dan dat immaterieel kapitaal persoonsgebonden is, dan wordt één van de meest fundamentele grondslagen van de control op gedelegeerd eigendom, het niet delegeren van het vervreemdingsrecht, aangetast.

- Een tweede fundament van een effectieve management control is dat deze berust op de aanwezigheid van social capital, een stabiel sociaal systeem van onderling vertrouwen, zoals dat ook ten grondslag ligt aan het marktmechanisme. Als nu, wat Sennett (1998) schrijft, door flexibilisering, door teamwork, door te werken met self employed kenniswerkers, dit social capital aangetast wordt, wordt ook deze grondslag onder management control aangetast.

- Een derde element in management control is dat steeds wordt uitgegaan van self control, het individu wil er trots op zijn dat een hem gestelde taak door hem goed wordt uitgevoerd zonder voortijdig ingrijpen door anderen. Deze self control veronderstelt dat de mens zichzelf ziet in relatie tot de ander en in relatie tot een verhaal dat hij zichzelf over zijn eigen toekomst heeft gemaakt. Het ontbreken van die twee elementen, wat gesuggereerd wordt in de beschrijving van de postmoderne mens, impliceert dat self control als één van de grondslagen onder management control op zijn minst verzwakt is (tenzij er co-locatie is tussen kennis, beslissingsrechten en direct recht op de daaruit voortvloeiende eigendomsrechten).

- In de vierde plaats geldt als fundament onder management control de controlable mens, het individu dat zich wil schikken in een groter systeem, daarin weliswaar ook zijn eigen motieven nastreeft en dus zo nu en dan gecorrigeerd moet worden, maar in essentie zich wil schikken. Ten minste een aantal auteurs over het postmodernisme schilderen een beeld van de postmoderne mens die zich niet meer wil of kan schikken in grotere systemen. Gedragsbeïnvloeding ging steeds uit van het verwachtingsmodel van Vroom voor motivatie, waarin het individu gevoelig is voor de relatie tussen inspanning, resultaten en beloning. Maar wat nu als de medewerker vooral er op uit is om te spelen (Himanen, 2001), wanneer zijn beloning vooral daarin ligt dat hij toegang heeft tot bepaalde werkzaamheden, mensen en kennis? Als dit laatste het geval is, is dan de enige weg voor herstel van gedragscontrol die gesuggereerd door Jensen: dat arbeidscontracten worden omgezet in leveringscontracten, waarmee een co-locatie tussen eigendom, beslissingsbevoegdheid, kennis en het vruchtgebruik daarvan wordt gerealiseerd?

- Een vijfde element is de drager van waarde. In de traditionele management accounting/control is het fysieke object, telbaar, meetbaar, ruimtelijk, observeerbaar, controleerbaar. Rifkin schetst het beeld dat de exploitatie van immateriële goederen weliswaar fysieke goederen nodig heeft, computers, internet, maar de waarde van immateriële goederen overtreft in zijn analyse die van fysieke goederen, die bovendien minder onderwerp worden van transacties. Hoe moet de kostprijs van diensten aangeboden via internet worden bepaald, als in wezen het internet oneindige capaciteit heeft en de diensten elkaar beïnvloeden in waarde en de waarde, zeker in het geval van standaarden, bepaald wordt door het aantal gebruikers. Controle over de eigendom van niet-fysieke goederen, zo leert ook de MP3-case ${ }^{2}$, is een lastige zaak, en daarmee ook het aspect van de bescherming van de waarden van de onderneming als onderdeel van management control.

- Een zesde element ten slotte heeft te maken met de bestuurbaarheid van de onderneming. In de traditionele managementtechnieken wordt verondersteld dat de visie van het management en het belang van de onderneming als geheel te verenigen is met de zienswijzen en belangen van de medewerkers. De door Lindijer beschreven postmoderne mens identificeert zich eerder met het - lokale - afdelingsbelang en heeft moeite zich met de onderneming als geheel, met het vennootschappelijk belang te identificeren. Het gaat hierbij niet alleen meer, wat steeds het geval is geweest, om het eigen lijfsbehoud, maar een principiële keuze voor het lokale, met een ontkenning, als al niet een verzet tegen het grotere geheel. Dit lokale 
georiënteerd zijn roept bij de leiding van de onderneming een reactie op in de vorm van het eisen van intensievere rapportages en het opzetten van cultuurprogramma's (die deels erop gericht zijn dat medewerkers zich met de onderneming als geheel identificeren, deels to control the uncontrolable) ${ }^{3}$.

Mogelijk wordt of is het grootste probleem van onze tijd de groei van postmoderne exploitatie van cultuur en experiences, waarvoor traditioneel-modernistische organisaties nodig zijn voor de uitvoering. Het gevolg daarvan is dat managers en werknemers steeds sterker in twee werelden komen te leven. Dit kan een vervreemdingseffect tot gevolg hebben zoals die ook rond 1900 heeft bestaan. De vraag is dan hoe individuen en in het bijzonder professionals als controllers in hun persoonlijk leven en in hun beroepsleven daarmee omgaan (Kunneman, 1996: hoofdstuk 8, Normatieve professionaliteit). Die vervreemding zal ten minste tot gevolg hebben dat de regels van de organisatie waar men werkt niet geïnternaliseerd worden, terwijl management control er vanuit gaat dat het merendeel van de medewerkers zich de regels van de organisatie internaliseren. De postmoderne houding impliceert dat niet-geïnternaliseerde regels die men voor zijn inkomen nodig heeft niet ter discussie worden gesteld, terwijl tegelijk de postmoderne professional er een spel mee speelt. Immers de hoogopgeleide weet de regels toe te passen zonder internalisatie daarvan, voor hem is er geen onderscheid tussen de regels van de organisatie waarin hij werkt en die van het spel Monopoly. Een andere consequentie is dat voor de postmoderne medewerker geldt dat hij geen onderdeel is van een arbeidsorganisatie, maar de arbeidsorganisatie is één van de onderdelen in zijn leven. Daarmee vervalt de loyaliteit aan de organisatie die voorondersteld wordt in het beginsel van self-control.

Het lijkt erop alsof het postmodernisme de noodzaak van management control ondermijnt. Immers we hebben control nodig omdat we zaken willen realiseren, (zie ook wat over het utopisme is geschreven, Bloch, 1959; Polak, 1957), die niet voortkomen uit de natuurlijke gang van zaken of uit ons gewone doen (Merchant, 1998). Maar als dan de postmoderne mens zich geen doel stelt, slechts met het hier en nu op een speelse wijze bezig is, immers het post-modernisme is synoniem aan het einde van het utopisme, dan lijkt daarmee ook de noodzaak voor management control te vervallen. Zie ook de discussies over organische organisaties, veranderingsprocessen zonder doel en zelforganiserende systemen. Het eerder geschetste delegitimiseringsproces in de samenleving lijkt daarmee ook het instituut management control zelf te raken.

\section{Hoe verder met het vakgebied management control?}

Op dit moment is de algemene tendens de effectiviteit van management control te verbeteren door toepassing van technieken als de balanced scorecard en allerlei andere hulpmiddelen. Ook toepassing van kennismanagementtechnieken is een voorbeeld van een poging tot het 'herstellen' van de - traditionele management control. In het voorgaande hebben we gezien dat de problemen met betrekking tot de effectiviteit van de management control veel diepere oorzaken heeft. In essentie is er sprake van een eigendomsvraagstuk. De implicatie daarvan is dat dan ook in termen van eigendomsverhoudingen het vraagstuk van management control in de nieuwe economische verhoudingen aangevat zal moeten worden. Daarvoor zal naar andere organisatievormen (eigendomsrechten, juridische vormen, operationele vormen) moeten worden gezocht die beter passen bij de exploitatie van kennis die niet belichaamd is in discrete fysieke producten (Strikwerda, 2001; Strikwerda en Van Dedem, 2000). De andere rol van arbeid in het leven van het individu in combinatie met persoonsgebonden kennis zal zich mogelijk moeten vertalen in vernieuwing van het arbeidsrecht en arbeidscontracten, dit is een nog onontgonnen terrein. Het vraagstuk van de legitimiteit van regels, normen en waarden is een maatschappelijk vraagstuk, waarvan de oplossing buiten het vakgebied management control ligt, maar zie de ontwikkelingen in de USA, deels worden afgewenteld op accountingregels en management control. In ieder geval kan uit het voorgaande worden geconcludeerd dat organisatiecultuur geen oplossing biedt voor het realiseren van een effectievere management control. Evenzeer is terughoudendheid gepast bij het verder verfijnen van instrumenten en control-parameters, dit raakt niet de kern van de zaak. Tegelijk geldt dat de traditionele management control overeind moet worden gehouden en efficiënter zal moeten worden omdat onder nieuwe vormen van economische exploitatie de traditionele blijven bestaan, zij het onder grote kostendruk en minder hoge opbrengsten dan in het verleden.

Waar het vakgebied management control zelf zich op zal moeten concentreren, is dat steeds vaker, in steeds meer situaties eigendomsverhoudingen (franchise, ESOP) een variabele zal moeten zijn in het realiseren van effectieve control (Jensen, 1998). Dit is overigens 
wel een gecompliceerde zaak, omdat het ernaar uitziet dat in de Europese verhoudingen andere oplossingen werkbaar zullen zijn dan die effectief bleken in de Amerikaanse verhoudingen.

Dit artikel doet ook inzien dat de verdere ontwikkeling van het vakgebied management control gedifferentieerd moet worden voor de verschillende vormen van exploitatie in de economie. Dat de postmoderne mens anders staat tegenover hiërarchie, wet en gezag kan niet worden beantwoord met meer aandacht voor soft controls, maar moet juist worden beantwoord met een betere invulling van contractuele verhoudingen. Het vakgebied management control moet zich niet concentreren op het vermeende fenomeen van postmoderne organisaties, maar op de fundamentele veranderingen in de economie en zijn instituties die de grondslagen van het vakgebied raken. Alleen dan kan de crisis in het internationale governance systeem worden voorkomen, immers geen corporate governance zonder internal governance.

\section{Literatuur}

Anderson, P., (1998),. The Origins of Postmodernity,. Verso, London. Anthony, R.N. en V. Govindarajan, (1995),. Management Control Systems (8th ed.), Irwin Chicago.

Best, S. en D. Kellner, (2001), Kevin Kelly's Complexity Theory: The Politics and Ideology of Self-Organizing Systems,. http://www.uta.edu/huma/ illuminations/best7.htm. Accessed: 28-03, 2002.

Bloch, E., (1959),. Das Prinzip Hoffnung,. Suhrkamp, Frankfurt am Main.

Boje, D., (2001),. What is Critical Postmodern Theory? http://cbae.nmsu. edu/ dboje/pages/critpomo_page. Accessed: 29-3, 2002.

Boje, D.M. en L. Prieto, (2000),. What is Postmodern?, http://cbae. nmsu.edu/ -dboje/mpw.html. Accessed: April 17, 2002.

Bradley, M., C.A. Schipani, A.K. Sundaram en J.P. Walsh, (2000), The Purposes and Accountability of the Corporation in Contemporary Society: Corporate Governance at a crossroads,. www.ssrn.com. Accessed: September.

Brockway, G.P., (2001),. The End of Economic Man: An Introduction to Humanistic Economics (fourth ed.),. W.W. Norton \& Co., New York.

Castells, M., (1996),. The rise of the network society,. Blackwell, Mass.

Clegg, S.R., (1990),. Modern Organizations -- Organization Studies in the Postmodern World,. Sage Publications, London.

DeLong, J.B. en L.H. Summer, (2001),. The 'New Economy': Background, Questions, and Speculations,. www.SSRN.com: U.C. Berkeley/NBER/ Harvard University.

Drucker, P.F., (1993), Post-Capitalist Society, HarperCollins, New York.

Economist, T. (2003). "Lights! Camera! No profits!" The Economist, 366 , January 18 (8307), 11-12.

Furubotn, E.G. en R. Richter, (2000),. Institutions and Economic Theory: The Contribution of the New Institutional Economics,. The University of Michigan Press, Ann Arbor.
Giddens, A., (1991),. Modernity and Self-Identity: Self and Society in the Late Modern Age, Polity Press, Cambridge.

Himanen, P., (2001),. De hacker ethiek en de geest van het informatietijdperk (M.-C. van Spaendonck, Trans.),. Nieuwezijds, Amsterdam.

Hodgson, G.M., (1988),. Economics and Institutions: A Manifesto for a Modern Institutional Economics,. Polity Press, Cambridge.

Hofstede, G., (1981), Management Control of Public and Not-for-profit Activities, in: Accounting, Organizations and Society, vol. 6, pp. 193-211.

Jensen, M.C., (1998),. Foundations of organizational strategy,. Harvard University Press, Cambridge, Mass.

Jensen, M.C., (2000),. A Theory of the Firm: Governance, Residual Claims, and Organizational Forms, Harvard University Press, Cambridge, Mass.

Kunneman, H., (1996),. Van theemutscultuur naar walkman-ego: Contouren van postmoderne individualiteit,. Boom, Amsterdam.

Lindijer, C.H., (1998),. Postmodern bestaan: Menszijn en geloven in een namoderne cultuur (tweede ed.),. Boekencentrum, Zoetermeer.

Merchant, K.A., (1998),. Modern Management Control Systems,. Prentice Hall, Upper Saddle River, NJ.

Myerson, G., (2001),. Ecology and the End of Postmodernity, Icon Books, Duxford, Cam.

North, D.C., (1990),. Institutions, Institutional Change and Economic Performance,. Cambridge University Press, Cambridge.

Ouchi, W.G., (1979), A Conceptual Framework for the Design of Organizational Control Mechanisms, in: Management Science, vol. 25(9), pp. 833-848

Polak, F.L., (1957),. Hoopvolle toekomst perspectieven,. De Haan, Zeist.

Rifkin, J., (2000),. The Age of Access: The new culture of hypercapitalism where all of life is a paid-for experience,. Penguin Putnam, New York.

Sennett, R., (1998),. The Corrosion of Character: The Personal Consequences of Work in the New Capitalism,. W.W. Norton, New York.

Shy, Oz, (2001), The Economics of Network Industries, Cambridge University Press.

Strikwerda, J., (2000). Internal governance: Leiding en organisatie in de nieuwe economie,. Vossiuspers AUP, Amsterdam.

Strikwerda, J.. (2001),. Nieuwe-werkende-organisatievormen,. in: Holland Management Review, vol. 18(77), pp. 8-22.

Strikwerda, J. en G.M. van Dedem,. (2000),. Governance issues and models,. iln J.T.M. van der . d Zee en J. Strikwerda (Eds.), Changing Business Designs for the 21st Century. Addison Wesley Longman Nederland B.V., Amsterdam.

Watson, T.J., (2002),. Organising and Managing Work: Organisational, managerial and strategic behaviour in theory and practice.. Pearson Education, London.

Zijderveld, A.C., (2000),. The Institutional Imperative: The Interface of Institutions and Networks,. Amsterdam University Press, Amsterdam.

\section{Noten}

1 Of er sprake is van een nieuwe of andere economie is omstreden, zie mijn oratie (Strikwerda, 2000) voor bronnen over die discussie. In ieder geval zijn fenomenen als e-commerce, internet en dergelijkee.d. op zich geen vormen van economische activiteit met andere wetmatigheden. Toch is er een aantal fenomenen die impliceren dat traditionele (bedrijfseconomische) verhoudingen niet meer opgaan: de 


\section{FINANCIEEL MANAGEMENT}

exploitatie van kennis zonder dat deze belichaamd behoeft te zijn in discrete fysieke goederen, externaliteiten met positive returns, de dominantie van network industries (Shy, 2001) over traditionele manufacturing industries, de rol van standaarden met als gevolg natuurlijke monopolies, zijn enkele ontwikkelingen die een aantal macro-economen doen concluderen dat er toch iets is als een andere economie.

2 MP3 is een software standaard die het eenvoudig heeft gemaakt voor consumenten om muziek in digitale computerbestanden om te zetten, op te slaan en met elkaar uit te wisselen via het internet, te downloaden op speciale draagbare spelers waarmee die muziek wordt beluisterd. Het gevolg is dat veel jongeren geen cd's meer kopen maar in hun behoefte aan muziek voorzien via internet (van zogenoemde Napstar-like file-sharing services), waardoor ze niets voor muziek meer hoeven te betalen. Deze on line piracy strekt zich inmiddels uit tot kranten en de filmindustrie en veroorzaakt een inkomensderving van honderden miljoenen dollars bij de producenten van muziek, nieuws en film. Economist, Lights! Camera! No profits! .

3 Eén van de reviewers wijst er op dat auteurs als Simons (1995), Ouchi (1979) en Hofstede (1981) besteden ook aandacht besteden aan cultuur als factor in management control. De oplossingen die deze auteurs aandragen, met uitzondering van Simons' interactive control, berusten echter op het mensbeeld zoals dat wordt gehanteerd in de neo-klassieke economie (voor een kritiek daarop zie onder meer Brockway, 2001.The End of Economic Man: An Introduction to Humanistic Economics en Hodgson, Economics and Institutions: A Manifesto for a Modern Institutional Economics Bovendien bestaan er ernstige bezwaren tegen cultuur als instrument voor control: 'However, cultural control is problematic in the best of times, and scholars have pointed out that this kind of hegemonic control insidiously robs individuals of their humanity. John van Maanen and Gideon Kunda's work, for example, traces the evolution in the various approaches to the control of individuals in organizations and concludes by worrying about the 'social molestation' that marks such contemporary approaches to control (zie Bradley, et al., 2000). The Purposes and Accountability of the Corporation in Contemporary Society: Corporate Governance at a Crossroads. 